\title{
The Implementation of Problem Based Learning Model in Improving the Generic Science Skill of Organic Chemistry on Teacher Candidates
}

\author{
Ratu Evina Dibyantini \\ Department of Chemistry Education \\ Universitas Negeri Medan \\ Medan, Indonesia \\ E-mail: ratuevina1962@gmail.com
}

\author{
Etno Dwi Suyanti \\ Department of Chemistry Education \\ Universitas Negeri Medan \\ Medan, Indonesia
}

\author{
Ramlan Silaban \\ Department of Chemistry Education \\ Universitas Negeri Medan \\ Medan, Indonesia
}

\begin{abstract}
The Implementation of Problem Based Learning Models in Improving the Generic Science Skills of Organic Chemistry On Teacher Candidates. This study was aimed at investigating the improvement of teacher candidate students generic skill through problem based learning model on organic chemistry reactions subject. It was conducted by using quasiexperimental design with the non-equivalent pretest post-test control group. The subject of this study was done to teacher candidate students who took organic chemistry reactions subject, which consist of experimental class was taught by using problem based learning and control class was taught by direct instruction. The data was collected by using generic science skill test in the form of multiple choice tests and was treated by using SPSS version 20. The result of the study shows the implementation of problem based learning can improve students' generic skills with indicator: logic consistency, abstraction, symbolic language, modelling, logical inference, cause-effect and scale understanding.
\end{abstract}

Keywords- Problem based learning, Generic science skill, Organic chemistry reactions

\section{INTRODUCTION}

The quality of students' science mastery in Indonesia is still low. Based on the research conducted by Programme for International Students' Assessment (PISA), reported that in 2003 Indonesian students achievement in science was at rank 38 of 40 countries [1]. In 2006, was at 50 out of 57 countries [2], in 2009 was at 60 of 65 countries [3], in 2012 was at 64 of 65 countries [4], and in 2015 was at 62 out of 70 countries [5]. It is in line with the average score of science subject of National Examination in the last 3 years, they are 62.70 in 2015; 55.45 in 2016 and 57.80 in 2017 [6].

In order to increase the quality of chemistry education, LPTK as one of the board which responsible to prepare and produce chemistry teachers is asked to train their students as chemistry teacher candidates based on its standard competencies which includes four main competencies, namely: pedagogical competence, personality competence, social competences and professional competences. Those are integrated to teacher's job description [7].

One of the branches of chemistry is organic chemistry. Based on the result of case study at a University in North Sumatra, in the subject of organic chemistry 1 and 2 in the last three years, it is found that many students found it hard to study the concepts of organic chemistry. This phenomenon was shown from students' final average score, that was only $15 \%$ of them got A. However, organic chemistry lecturing activities always try to improve and strengthen students' comprehension about the concepts although in reality it is faced with many problems.

The reality shows that chemistry teachers in several high schools stated that organic chemistry subject which learned by teacher candidates in LPTK affected them minimally in teaching organic chemistry subject for senior high school. It is supported with the interview and questionnaire result of several teachers who stated that they found it hard to determine any types of organic reaction on high school Olympics questions. On his/her report was also reported that the organic chemistry concepts are considered as difficult to be understood, especially on the types of reaction, reaction mechanism and organic synthetic materials. Students tend to view organic chemistry concepts as an abstract concept which is difficult to understand. Besides, there are some concepts which are difficult to identify misconception. Some misconceptions which are mostly occur, namely: compound aromatic and its reaction concepts, types of organic reaction and organic reaction mechanism [8]. Thus, it is needed to find out how the comprehension of organic chemistry concepts can be right and increase their cognitive comprehension.

Problem Based Learning (PBL) has become a good alternative to improve students' comprehension of organic chemistry concepts. PBL is one of the learning methods that is developed in 25 years ago for medical education field, however it is now used in every level of education. This learning method involves students in an active, collaborative, 
student-centered learning process which develop their problem-solving and independent learning skills [9]. PBL is widely recognized as an effective learning strategy. In PBL, students are pushed to be familiar with the problem presented, forming a group, organizing the work, conducting a research and negotiating to answer the problems. Lecturer acts as a learning facilitator to define problems and guide the students in learning process. PBL is effective to motivate students to finish the problems in learning at chemistry laboratory [10]. One of the approaches in which students experience and find knowledge by themselves is PBL. In PBL, small group consists of 6 or 8 students with a tutor is made. The authentic and complex problem is given to help students to relate between theory and its application in reality, as well as developing their skills to overcome the complexity of reality [11].

To improve the quality, students as chemistry teacher candidate is needed to be provided with science generic skills, those are thinking skill and to act based on their scientific prior knowledge [12]. The generic skill in science is a skill related to science characteristics including chemistry [13]. Chemistry lecture, besides of providing students with chemistry material, it is also intended to give generic science skill. Thus, university is asked to provide students with generic science skills [14]. According to Khamsah in [15] generic science skills can be categorized into 9 indicators, they are: (1) direct observation; (2) indirect observation; (3) magnitude scale awareness; (4) symbolic language; (5) logic of obeying the principal framework; (6) logical interference; (7) law of cause and effect; (8) mathematical modeling; (9) concept construction.

This study is aimed at investigating the improvement of teacher candidate students' generic science skills through the use of problem based learning medel in organic chemistry reactions subject.

\section{RESEARCH METHODOLOGY}

This research was conducted in a quasi-experimental research with "one group pretest-posttest design". The subject of this research was the semester IV teacher candidate students of chemistry education program who took organic chemistry reactions subject in the year of 2017-2018 at Universitas Negeri Medan. The subjects were consists of two classes, one classes was experimental class with 21 students taught by using PBL model while the other as control class with 27 students taught by using direct instruction. The data was collected by using test in the form of multiple choice tests, 25 questions which had been validated by the expert were given to measure students' generic science skill. The data were students' pre-test and post-test score which were calculated before and after the learning process in either experimental or control class N-Gain formula by using SPSS version 20. As the requirement in doing data analysis, normality and homogeneity test were done previously.

\section{FINDINGS AND DISCUSSIONS}

Prequisites data analysis testing. Normality test was done to investigate whether the data was distributed normally. The normality data was tested by using Kolmogorov-Smirnov Test technique. Data is categorized as normally distributed if the probability score or $\mathrm{Sig}>0.05$. Since the score of $\operatorname{Sig}>\alpha$, then the data is normally distributed, as seen in the following table1.

TABLE 1. NORMALITY TEST

\begin{tabular}{|c|c|c|}
\hline Criteria & Group & Significance \\
\hline \multirow{2}{*}{ Pre-test } & Experiment & 0.448 \\
\cline { 2 - 3 } & Control & 0.620 \\
\hline \multirow{2}{*}{ Post-test } & Experiment & 0.192 \\
\cline { 2 - 3 } & Control & 0.375 \\
\hline \multirow{2}{*}{ N-gain } & Experiment & 0.522 \\
\cline { 2 - 3 } & Control & 0.560 \\
\hline
\end{tabular}

The calculation of homogeneity test from the data of experimental and control class was done with Compare Means by using SPSS version 20. The data is categorized as homogeny if the score of probability or Sig $>0.05$ because Sig $>\alpha$, then the data is homogeny. It can be seen in the Table 2 .

TABLE 2 HOMOGENEITY TEST

\begin{tabular}{|c|c|c|c|}
\hline No. & Criteria & Group & Significance \\
\hline \multirow{2}{*}{1.} & \multirow{2}{*}{ Pre-test } & Experiment & \multirow{2}{*}{0.100} \\
\cline { 3 - 3 } & & Control & \\
\hline 2. & \multirow{2}{*}{ Post-test } & Experiment & \multirow{2}{*}{0.160} \\
\cline { 3 - 3 } & Control & \multirow{2}{*}{0.115} \\
\hline \multirow{2}{*}{3} & \multirow{2}{*}{ N-gain } & Experiment & \\
& & Control & \multicolumn{2}{|c|}{} \\
\hline
\end{tabular}

After conducting prequisites data analysis testing, namely normality and homegenity test, the distributed normally and homogen data was obtained. Then, hypothesis testing by using SPSS program version 20 for windows can be done. The results of hypothesis testing are shown in Table 3.

TABLE 3 HYPOTHESIS TESTING RESULT

\begin{tabular}{|c|c|c|c|}
\hline Post-test Score & Sig. & $\boldsymbol{A}$ & t value \\
\hline $\begin{array}{c}\text { Equal variances } \\
\text { assumed }\end{array}$ & 0,000 & 0,05 & 21,379 \\
\hline
\end{tabular}

Based on the SPSS calculation, it was found Sig. (2-tailed) $0.000<0.05$ means $\mathrm{Ha}$ is accepted or Ho is rejected which means hypothesis is accepted and the validity is tested with the level $\alpha=0.05$; It can be concluded that there is a difference between students' learning achievement taught by using PBL method and eXe Learning media and not using eXe learning media.

The improvement of students' generic science skills is shown in Table IV which consists of the analysis of pre-test and post-test average score. N-gain and two sided test of significance with $95 \%$ of reliability to improve generic science skills in which the teacher candidate in experimental class was taught by using PBL and in control class by using Direct Instruction learning model. 
TABLE 4 The highest average score of post-test

\begin{tabular}{|c|c|c|c|c|}
\hline Class & $\begin{array}{c}\text { Number of } \\
\text { Students }\end{array}$ & $\begin{array}{c}\text { Average } \\
\text { score of } \\
\text { Post-test }\end{array}$ & $\begin{array}{c}\text { Average } \\
\text { Score of } \\
\text { Pre-test }\end{array}$ & N-gain \\
\hline Experiment & 21 & 87.80 & 23.62 & 0.83840 \\
\hline Control & 27 & 54,67 & 20,74 & 0.42212 \\
\hline
\end{tabular}

In the Table 4 , the highest average score of post-test is 87.80 for experimental class and the lowest average score of post-test is 54.67 for control class. Meanwhile, the highest average pre-test score is 23.62 for experimental class and the lowest average score of pre-test for control class is 20.74. From the table, it is seen $\mathrm{N}$-gain class is 0.84 which categorized as high achievement level while control class is 0.42 as medium achievement level. Therefore, it is found that PBL can improve generic science skill of chemistry teacher candidates. Based on Table IV, the average score of pre-test, post-test and N-gain of experimental and control class are seen in the following figure:

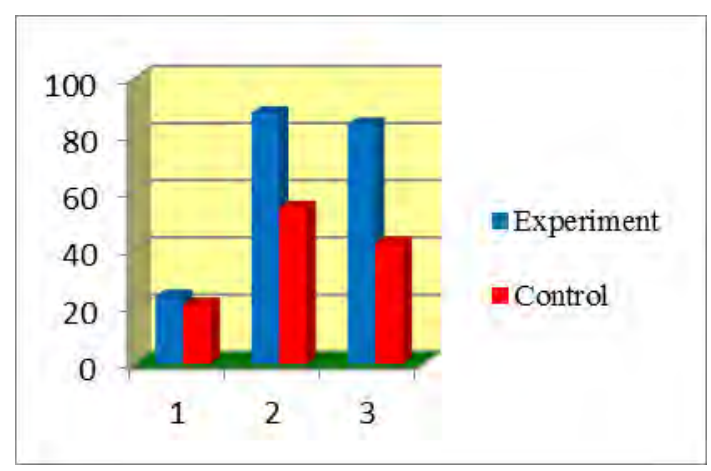

Fig. 1. The average score of pre-test, post-test and N-gain of experimental and control class

The indicator of generic science skills (GSS) were checked in this study and adjusted to organic chemistry reactions subject (addition, substitution, elimination). The indicators of developed generic science skill are logical consistency, abstraction, symbol language, modeling, logical inference, cause and effect as well as scale understanding. The percentage of average score of pre-test post-test and $\mathrm{N}$-gain from each indicator in experimental and control group are shown in the following table.

TABLE 5. PRE-TEST AND POST-TEST SCORE OF ALL GENERIC SCIENCE SKILL OF SCIENCE TEACHER CANDIDATES

\begin{tabular}{|c|c|c|c|c|c|c|c|c|}
\hline \multirow{2}{*}{ No. } & \multirow{2}{*}{ GSS } & \multicolumn{3}{|c|}{ Control Group } & \multicolumn{3}{|c|}{ Experimental Group } & ff Problem Based Learning model can imnrove generic \\
\hline & & Pretest & Posttest & $\mathrm{N}$-gain & Pretest & Posttest & N-gain & skills of chemistry teacher \\
\hline 1. & GSS 1 & 9,92 & 21,92 & 0,35 & 11,23 & 39,42 & 0,8604 & cience skins of chemistry teacher candidate students with \\
\hline 2. & GSS 2 & 4,88 & 12,44 & 0,50 & 5,90 & 15,62 & 0,6891 & action, symbol languag \\
\hline 3. & GSS 3 & 0 & 0 & 0 & 1,14 & 4 & 1 & nd effect as well as sca \\
\hline 4. & GSS 4 & 3,85 & 12,29 & 0,52 & 5,33 & 17,52 & 0,8311 & understanding. \\
\hline 5. & GSS 5 & 0,59 & 1,92 & 0,39 & 1,14 & 3,04 & 0,6667 & \\
\hline 6. & GSS 6 & 0,88 & 3,25 & 0,76 & 0,95 & 4 & 1 & \\
\hline 7. & GSS 7 & 0,59 & 2,81 & 0,65 & 1,14 & 4 & 1 & \\
\hline
\end{tabular}

\section{Information:}

GSS 1: Logical Consistency GSS 2: Abstraction
GSS 3: Symbolic Language

Understanding

GSS 4: Modelling

Table 5 indicates that generic science skills of each indicator in experimental and control group had improved. It showed that learning model could improve generic science skills. It is in line with the study conducted by [16] who stated that learning model affects the improvement of generic science skills. [15] also stated that generic science skills can be improved by using PBL. The indicator of generic science skill of experimental and control group are shown in the following figure:
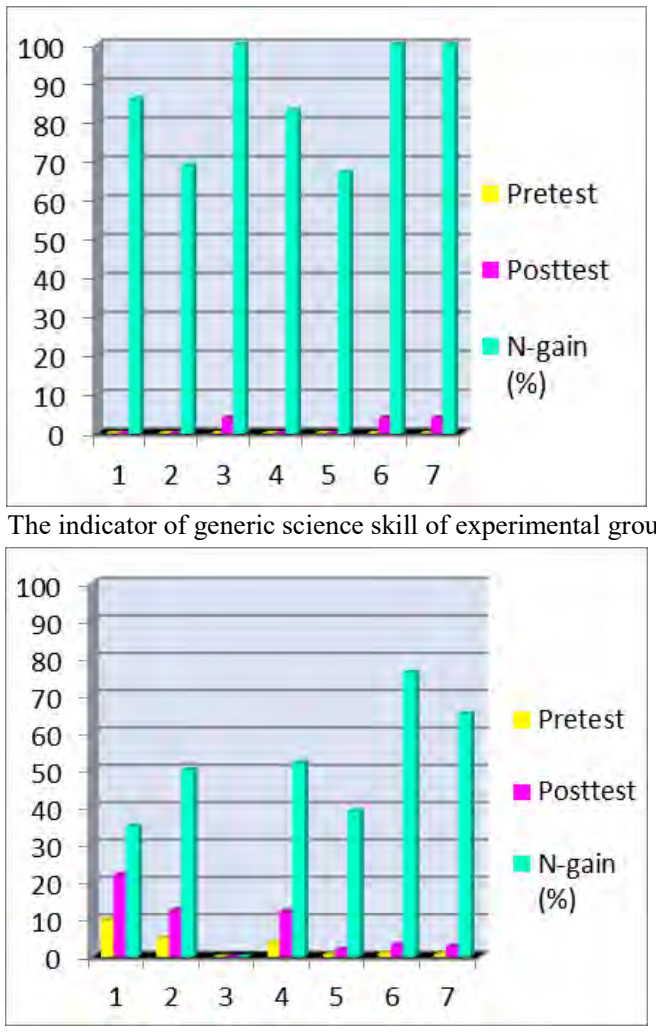

Fig. 3. The indicator of generic science skill of control group

\section{CONCLUSION}

Based on the problem of the study, result and discussion as it is stated above, it can be concluded that the implementation of Problem Based Learning model can improve generic cience skills of chemistry teacher candidate students with
Fig. 2. The indicator of generic science skill of experimental group 


\section{ACKNOWLEDGMENT}

The writer would like to express her deep gratitude to Indonesian Directoral Research.

\section{REFERENCES}

[1] OECD, "PISA 2003 Technical Report", OECD Publishing, PISA, 2005

[2] OECD, "PISA 2006 Science Competencies for Tomorrow 's World", OECD Publishing, PISA, 2009

[3] OECD, "PISA 2009 Results : Executive Summary, OECD Publishing, PISA, 2010

[4] OECD, "PISA 2012 Result in Focus : What 15-year-olds know and what they can do with what they know", OECD Publishing, PISA, 2014

[5] OECD, "Programme for International Student Assesment (PISA) Result from PISA 2015", OECD Publishing, PISA, 2016

[6] Kemendikbud., "Permendikbud Nomor 22 Tahun 2016 Tentang Standar Kompetensi Lulusan Pendidikan Dasar dan Menengah", Kemendikbud, Jakarta, 2016

[7] Pusat Kementrian Pendidikan dan Kebudayaan, "Kumpulan Nilai Ratarata UN Kimia", Puspendik, 2017

[8] Ruckiyat, "Penerapan pembelajaran Konflik Kognitif Upaya Meningkatkan Penguasaan Konsep dan Berpikir Kritis Mahasiswa Pada Materi Reaksi-reaksi Senyawa Organik: Program Studi pendidikan IPA ", UPI: Unpublished Thesis, 2017
[9] S.Gallagher, W.J.Stepien, B.T.Sher, and D.Workmen, Implementing Problem-Based Learning in Science Classroms: School Science and Mathematics", 95(3), 136-146, 1995

[10] P.Ram, "Problem-Based Learning In Undergreduate Education: A Sophomore Chemistry Laboratory", Journal of Chemical Education. Vol. $76(8), 1999$

[11] A.K. Tasoglu, and M. Bakac, "The efect of Problem Based Learning Approach on Conceptual Understanding in Teaching of Magnetism Topics", Eurasian Journal of Physics and Chemistry Education 6(2) : 110-122, 2014

[12] Liliasari, "Pengembangan Keterampilan Generik Sains Untuk Meningkatkan Kemampuan Berpikir Kritis Siswa”, Jurnal Jurusan Pendidikan Kimia, 2011

[13] S.Mulyani, "Pembekalan Keterampilan Generik Kimia Bagi Mahasiswa Calon Guru Melalui Inkuiri Pada Mata Kuliah Kimia Fisika III", Sekolah Pascasarjana UPI. Bandung: Tidak diterbitkan, 2012

[14] M. Anwar, A. Liliasari, Setiabudi, \& M.A. Martoprawiro, "Desain Lembaran Kerja Berbasis Pembelajaran Aktif- Kooperatife untuk Meningkatkan Ketrampilan Generik Sain Mahasiswa (Penerapan Pada Topik Mekanisme Reaksi)", Jurnal Chemica, 13(1), 1-13, 2012

[15] H. Zakiyah., Adlim, \& A. Halim, "Implementasi Model Pembelajaran Berbasis Masalah Pada Materi Titrasi Asam Basa Untuk Meningkatkan Keterampilan Generik sains Mahasiswa Program Studi Pendidikan Kimia", Lantanida Journal, 1, 2014

[16] R. D. Suyanti, "Pembekalan Kemempuan Generik Bagi Calon Guru Melalui Pembelajaran Kimia Anorganik Berbasis Multimedia Komputer", Sekolah Pascasarjana UPI. Bandung: Tidak diterbitkan, 2006 